\title{
Kamu Yapılarının Hurda Karşılığı Yıkımı ve Kamu Gelirlerine Katkısı
}

\author{
Burak ÖZ ${ }^{* 1}$ (1), Murat ANBARCI ${ }^{2}$ (1) \\ ${ }^{1}$ Zonguldak Bülent Ecevit Üniversitesi, Mühendislik Fakültesi, İnşaat Mühendisliği Bölümü, 67100, Zonguldak \\ ${ }^{2}$ Sultanbeyli Belediye Başkanlığı, Abdurrahmangazi Mahallesi, Belediye Caddesi No: 4 Sultanbeyli, İstanbul
}

(Alınış / Received: 27.08.2020, Kabul / Accepted: 10.02.2021, Online Yayınlanma / Published Online: 15.04.2021)

Anahtar Kelimeler İnşaat ve yıkıntı atıkları, Geri dönüşüm, İnşaat yönetimi, Muhammen bedel, Kamu yıkım işleri
Özet: Bu çalışmada, Avrupa Birliği Ülkelerinde ve Ülkemizdeki inşaat ve yıkıntı atıklarının tekrar kullanımı, geri dönüşümü ve yıkıntı malzemelerin geri kazanımıyla ilgili genel bilgiler verilmiş ve kamu binalarının hurda karşılı̆̆ yıktırılması süreci analiz edilerek buradan elde edilecek kamu gelirinin artırılmasına yönelik çözüm önerilerinin sunulması amaçlanmıștır. Kamu idarelerinin 2016 ile 2020 yılları arasında yapmış oldukları tüm hurda karşılı̆̆ı yıkım işleri incelenmiştir. İhaleye çıkılan iki yüz beş (205) iş için ilgili kamu idareleriyle temasa geçilerek yapmıș oldukları ișler ile ilgili sözleșme bedelleri ile bu işlerin muhammen bedel hesaplama yöntemine ilişkin bilgiler talep edilmiştir. Elli dokuz işle ilgili elde edilmiş verilerin değerlendirilmesi sonucunda muhammen bedelin hesaplanmasında farklı yöntemler kullanıldığı görülmüsstür. Bunlar; metraj hesabı yapılmış ve kamu kurumlarının yayımladıkları birim fiyatlar kullanılmış, metraj hesabı yapılmıs ve birim fiyatlar için piyasa araștırması yapılmıș, sadece piyasa araştırması yapılmış veya ihaleye çıkacak idare kendi tecrübesine dayanarak tahminde bulunmuştur. İhalesi yapılıp sözleşmeye bağlanan işlerde muhammen bedel ile sözleșme bedeli arasında ciddi dalgalanmalar olduğu ancak bu durumun muhammen bedel hesaplama yöntemiyle bir ilişkisinin olmadığı görülmüștür. Yaptığımız değerlendirmede, muhammen bedelin değerinden çok altında tahmin edilmesi ve ihalede yeterli rekabetin oluşmaması durumunda kamu gelirinde ciddi kayıplar meydana gelebileceği sonucuna ulaşılmıştır.

\section{Public Demolition Works for Scrap and Contribution to Public Revenues}

\section{Keywords}

Construction and demolition waste,

Recycling,

Construction management,

Estimated value,

Public demolition works

\begin{abstract}
General information about reuse, recycling and materials recovery of construction and demolition waste in European Union Countries and in Turkey has been given and it has been aimed to analyze the process of demolition of public buildings for scrap, and to propose solutions to increase public revenues. We have examined all demolition works for scrap contracted by public authorities and institutions between the years of 2016 and 2020. We have contacted the relevant public authorities and institutions that put out to tender for two hundred and five demolition works and requested information regarding the contract prices and the method of calculating the estimated value related to these works. As a result of evaluating the data obtained for fifty-nine demolition works, it has been observed that different methods are used in the calculation of the estimated prices. These are; the quantity calculation of demolition waste and the use of the unit prices published by the public authorities, the quantity calculation of demolition waste and the demolition experts' proposals for the unit prices, only the demolition experts' proposals for the works, or the relevant public authority's estimation based on its own experience. It has been observed that there is a serious fluctuation between the contract price and the estimated price in the contracted demolition works, however we have seen that there is no relation with the method of calculation of the estimated prices. In our evaluation, it was concluded that serious losses in public income may occur in case the estimated price is undervalue and if there is not enough competition in the tender.
\end{abstract}




\section{Giriş}

İnşaat işlerinde, doğal kaynakların, özellikle yenilenemeyen kaynakların kullanılması, her yıl milyonlarca ton inşaat ve yıkım atığına yol açmaktadır. Çoğu ülkede bu malzemeler için özel bir işleme planı bulunmadığından, yeniden kullanmak ve/veya geri dönüştürmek yerine atık depolama alanlarında depolanmaktadır [1].

2016 yllında, tüm ekonomik faaliyetler ve hane halkları tarafından AB'de üretilen toplam atık miktarı 2.538 milyon ton olup, bunların \% 45,7'si atık sahasında depolanmış ve \% 37,8'i ise geri dönüştürülmüştür. Toplam atığın yaklaşık \% 36,4' ü (923 milyon ton) inşaat ve yıkıntı atıklarından kaynaklanmaktadır [2]. Yirmi sekiz Avrupa Birliği Ülkesinin 2016 yılı itibarıyla inşaat ve yıkıntı atıklarının ortalama \%89'u geri kazanılmıştır [3]. Tablo 1'de bazı Avrupa Ülkelerinin inşaat ve yıkıntı atıkları geri kazanım oranları verilmekte olup Türkiye ile ilgili veri bulunmaması dikkat çekmektedir [4].

Ülkemizde ise inşaat ve yıkıntı atıkları miktarının ylllık 4-5 milyon ton olduğu tahmin edilmektedir [5]. Hafriyat, inșaat ve yıkıntı atıkları yönetimi ile oldukça sınırlı veri girişi yapılmıştır. 2014 yılında yaklaşık 100 milyon tonun üzerinde hafriyat toprağı, inşaat ve yıkıntı atığı geri kazanılmış ya da bertaraf edilmiştir. 2023 yılında ise yaklaşık 300 milyon ton hafriyat toprağı ve inşaat ve yıkıntı atığının oluşması beklenmektedir [6]. Ortalama olarak her bir metreküp inșaat/yıkıntı atı̆̆ndan yaklașık olarak 0,60 metreküp malzeme geri dönüștürülebilmektedir [7].

\section{1. İnşaat ve Yıkıntı Atıklarının Kullanım Alanları ve Sinıflandırılması}

Konut, bina, köprü, yol ve benzeri alt ve üst yapıların yapımı esnasında ortaya çıkan atıklar inşaat atıklarını oluştururken bu yapıların tamiratı, tadilatı, yenilenmesi, yıkılması sonucunda ortaya çıkan atıklar ise yıkıntı atıklarını oluşturmaktadır. Bu atıklardan bazıları içersinde asfalt, zift, doğal polimer ve benzeri malzemeler bulunurken bazlları içersinde ise asbest, boya, floresan ve benzeri zararlı ve tehlikeli maddeler bulunmaktadır. Bunlar, tehlikeli inșaat ve yıkıntı atıkları olarak sınıflandırılır [8].

Ülkemizde "Hafriyat Toprağı, İnșaat ve Yıkıntı Atıklarının Kontrolü Yönetmeliği” 18.03.2004 tarih ve 25406 sayı ile yayımlanarak 2010 yılında yürürlüğe girmiştir. $\mathrm{Bu}$ yönetmek inşaat ve yıkıntı atıklarının toplanması, geçici biriktirilmesi, taşınması, tekrar kullanılması, geri dönüşümü ve bertaraf edilmesiyle ilgili düzenlemeleri yapar [8]. Şekil 1'de bu yönetmelikten istifade edilerek hazırlanmış hafriyat toprağı, inşaat ve yıkıntı atıkları kullanım alanları gösterilmiştir.

Tablo 1. İnșaat ve yıkıntı atıklarının geri kazanım oranları

\begin{tabular}{|c|c|c|c|c|c|c|c|c|c|}
\hline \multicolumn{10}{|c|}{$\begin{array}{c}\text { İnşaat ve yıkıntı atığının geri kazanım oranı } \\
\text { (tekrar kullanım + geri dönüşüm + geri kazanım + geri dolgu) / inşaat ve yıkıntı atığı }\end{array}$} \\
\hline \begin{tabular}{|l} 
ÜLKE \\
\end{tabular} & 2010 & 2012 & 2014 & 2016 & \begin{tabular}{|l} 
ÜLKE \\
\end{tabular} & 2010 & 2012 & 2014 & 2016 \\
\hline EU (28 countries) & $:$ & $:$ & 89 & 89 & Avusturya & 92 & 92 & 94 & 88 \\
\hline Belçika & 17 & 18 & 32 & 95 & Polonya & 93 & 92 & 96 & 91 \\
\hline Bulgaristan & 62 & 12 & 96 & 90 & Portekiz & 58 & 84 & 95 & 97 \\
\hline Çekya & 91 & 91 & 90 & 92 & Romanya & 47 & 67 & 65 & 85 \\
\hline Danimarka & $:$ & 91 & 92 & 90 & Slovenya & 94 & 92 & 98 & 98 \\
\hline Almanya & 95 & 94 & $: c$ & $: c$ & Slovakya & $:$ & $:$ & 54 & 54 \\
\hline Estonya & 96 & 96 & 98 & 97 & Finlandiya & 5 & 12 & 83 & 87 \\
\hline İrlanda & 97 & 100 & 100 & 96 & İsveç & 78 & 81 & 55 & 61 \\
\hline Yunanistan & 0 & 0 & 0 & 88 & Birleşik Krallık & 96 & 96 & 96 & 96 \\
\hline İspanya & 65 & 84 & 70 & 79 & İzlanda & 75 & 100 & 99 & 99 \\
\hline Fransa & 66 & 66 & 71 & $71^{\mathrm{e}}$ & Lihtenştayn & $:$ & $:$ & $:$ & $:$ \\
\hline Hırvatistan & 2 & 51 & 69 & 76 & Norveç & 44 & 75 & 77 & 71 \\
\hline İtalya & 97 & 97 & 97 & 98 & İsviçre & $:$ & $:$ & $:$ & $:$ \\
\hline Kibris & 0 & 60 & 38 & 57 & Karadağ & $:$ & $:$ & $:$ & 0 \\
\hline Letonya & $:$ & $:$ & 92 & 98 & Kuzey Makedonya & $:$ & 0 & 0 & $:$ \\
\hline Litvanya & 73 & 88 & 92 & 97 & Arnavutluk & $:$ & $:$ & $:$ & $:$ \\
\hline Lüksemburg & 98 & 99 & 98 & 100 & Sirbistan & $:$ & $:$ & $:$ & 80 \\
\hline Macaristan & 61 & 75 & 86 & 99 & Türkiye & $:$ & $:$ & $:$ & $:$ \\
\hline Malta & 16 & 100 & 100 & 100 & Kosova & $:$ & $:$ & $:$ & $:$ \\
\hline Hollanda & 100 & 100 & 100 & 100 & & & & & \\
\hline$:=$ mevcut değ & $\mathrm{e}=\mathrm{ta}$ & & & & & & & & \\
\hline
\end{tabular}


Bu oranların hesaplanmasında sadece tehlikeli madde içermeyen atıklar (beton, tuğla, alçı, yalıtım malzemeleri, karışık inşaat atıkları ve balast) göz önüne alınmıştır.

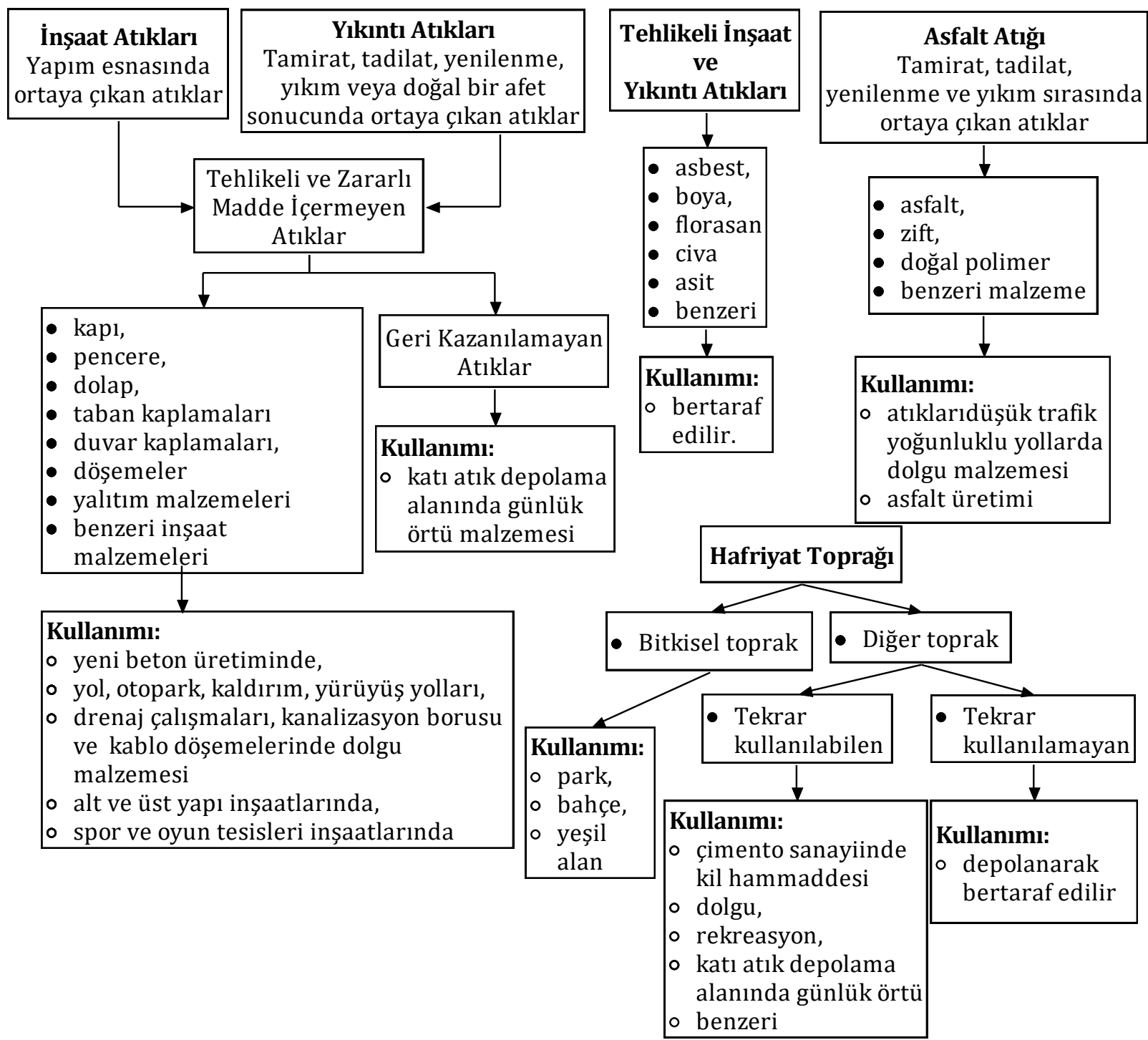

Şekil 1. Hafriyat toprağı, inşaat ve yıkıntı atıklarının kullanım alanları

Geri kazanılmış ürünler ilgili standartları sağlamak şartıyla öncelikle alt ve üst yapı inşaatları ile dolgu ve rekreasyon amaçlı kullanılmalıdır. Hafriyat toprağı uygun olması durumunda öncelikle çimento sanayinde kil hammaddesi olarak kullanılmalıdır. Hafriyat sırasında nebati toprak ayrı olarak toplanmalı, kesinlikle döküm alanına gönderilmemeli, yeșil alanlar ve benzeri çalışmalarda kullanılmalıdır. Nebati toprak dışındaki kazı hafriyat toprağı ise dolgu veya katı atık döküm alanlarında örtü amacıyla kullanılabilir, tekrar kullanılması mümkün değilse bertaraf edilir. Asfalt atıkları asfalt üretim tesislerinde veya yollarda dolgu malzemesi olarak kullanılabilir. Geri kazanılamayan inşaat ve yıkıntı atıkları ise ayrıştırma yapıldıktan sonra katı atık döküm alanlarında örtü malzemesi olarak kullanılabilir [8].

Atıkların sınıflandırılmasıyla ilgili olarak, Avrupa Atık Kataloğu ve Zararlı Atık Listesi 1 Ocak 2002 yılında yürürlüğe girmiş [9], ve Atık Sınıflandırma Rehberi 2 inci sürümü Aralık 2010 yılında yayımlanmıştır [10]. Ülkemizde de Atık Yönetimi Yönetmeliği, Avrupa Birliği mevzuatına uyum çerçevesinde Atık Sınıflandırma Rehberi esas alınarak hazırlanmış ve 2015 yılında yayımlanmıştır. İnşaat ve yıkıntı atıklarının sınıflandırılması ve kodları Şekil 2'de gösterilmiștir. Burada geçen $\operatorname{Kod}(\mathrm{K})$ : 17, Atık Yönetimi Yönetmeliği ekindeki Atık Kodu Belirleme Hiyerarşisi ve Atık Kodu Açıklamalarında geçen inşaat ve yıkıntı atıkları bölümünü göstermektedir. On yedi ile başlayan kodlar ise inşaat ve yıkıntı atık sınıflarını göstermektedir [11].

\subsection{Geri Kazanım ve Bertaraf Sistemi}

1999 yllında Avrupa Komisyonu için Symonds tarafindan hazırlanan "Construction And Demolition Waste Management Practices, And Their Economic Impacts" isimli final raporunda, ilgili tarihte Avrupa Birliğine üye on beş ülkenin inşaat ve yıkıntı atıkları 
ile ilgili veriler sunulmuştur. Bu veriler öncelikle

yetersiz olduğu yerlerde ise uzman görüşü alınmıştır. resmi kaynaklardan temin edilmiş, resmi kaynakların

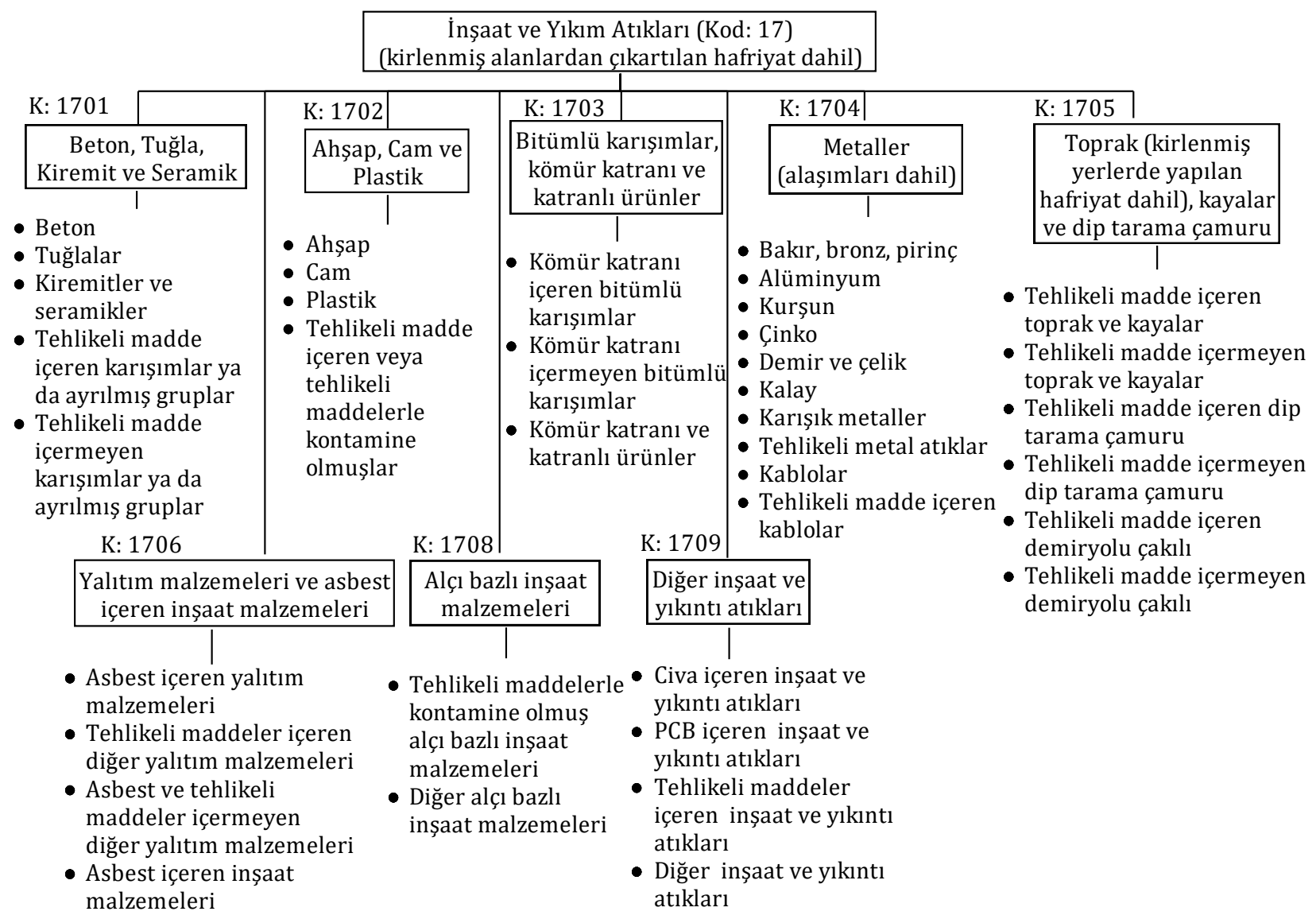

Şekil 2. İnşaat ve yıkıntı atıklarının sınıflandırılması

Tablo 2. Hafriyat toprağı, inșaat ve yıkıntı atıkları miktarları

\begin{tabular}{|c|c|c|c|c|c|c|c|c|c|}
\hline \multicolumn{10}{|c|}{ Hafriyat toprağı, inşaat ve yıkıntı atıkları kullanım miktarları (milyon ton) } \\
\hline Ülke & $\begin{array}{l}\text { Beton, tuğla, } \\
\text { kiremit, } \\
\text { seramik vs. } \\
\text { (inert) }\end{array}$ & Ahşap & Cam & Plastik & Metal & Yalıtım & Karışık & Hafriyat & Asfalt \\
\hline Almanya & 45 & & & & & & 14 & 215 & 26 \\
\hline İngiltere & \multicolumn{7}{|c|}{30} & 29,50 & 7,50 \\
\hline Fransa & \multicolumn{7}{|c|}{23,60} & & \\
\hline İtalya & \multicolumn{7}{|c|}{20} & & \\
\hline İspanya & \multicolumn{7}{|c|}{12,8} & & \\
\hline Hollanda & 10,48 & 0,26 & & 0,21 & 0,18 & & 0,04 & 6,20 & 2,72 \\
\hline Belçika & 6,41 & 0,11 & & 0,01 & 0,01 & & 0,21 & 27 & 0,91 \\
\hline Avusturya & 3,6 & & & & & & 1,1 & 20 & 1,70 \\
\hline Portekiz & \multicolumn{7}{|c|}{3,20} & & \\
\hline Danimarka & 1,80 & 0,20 & 0,05 & 0,01 & 0,16 & 0,05 & 0,37 & 7,70 & 0,37 \\
\hline Yunanistan & \multicolumn{7}{|c|}{1,80} & & \\
\hline İsveç & 1,12 & 0,39 & 0,01 & 0,00 & 0,15 & 0,02 & & 1,50 & 2,70 \\
\hline Finlandiya & 0,52 & 0,44 & 0,00 & 0,00 & 0,17 & 0,02 & 0,20 & 8 & 0,10 \\
\hline İrlanda & 0,39 & 0,01 & 0,01 & 0,00 & 0,01 & 0,00 & 0,15 & 1,31 & 0,01 \\
\hline Lüksemburg & \multicolumn{7}{|c|}{0,30} & & \\
\hline
\end{tabular}


Tablo 3. Hafriyat toprağı, inșaat ve yıkıntı atıklarının tekrar kullanım ve geri dönüșüm oranları

\begin{tabular}{|c|c|c|c|c|c|c|c|c|c|}
\hline \multicolumn{10}{|c|}{ Tekrar kullanım ve geri dönüşüm oranları } \\
\hline Ülke & $\begin{array}{c}\text { Beton, tuğla, } \\
\text { kiremit, seramik } \\
\text { vs. (inert) (\%) }\end{array}$ & $\begin{array}{c}\text { Ahşap } \\
\text { (\%) }\end{array}$ & $\begin{array}{l}\text { Cam } \\
\text { (\%) }\end{array}$ & $\begin{array}{c}\text { Plastik } \\
(\%)\end{array}$ & $\begin{array}{c}\text { Metal } \\
(\%)\end{array}$ & $\begin{array}{c}\text { Yalıtım } \\
(\%)\end{array}$ & $\begin{array}{c}\text { Karışık } \\
(\%)\end{array}$ & $\begin{array}{c}\text { Hafriyat } \\
(\%)\end{array}$ & $\begin{array}{c}\text { Asfalt } \\
(\%)\end{array}$ \\
\hline Almanya & 18 & & & & & & 14 & & 80 \\
\hline İngiltere & \multicolumn{7}{|c|}{45} & 41 & 80 \\
\hline Fransa & \multicolumn{7}{|c|}{15} & & \\
\hline İtalya & \multicolumn{7}{|c|}{9} & & \\
\hline İspanya & 75 & 3 & 0,5 & 1 & 2 & & 13,5 & & 5 \\
\hline Hollanda & 94 & 60 & & 17 & 100 & & 0 & 40 & 100 \\
\hline Belçika & 93,51 & 5 & & 10 & 90 & & 0 & & 100 \\
\hline Avusturya & 50 & & & & & & 15 & & 65 \\
\hline \multicolumn{10}{|l|}{ Portekiz } \\
\hline Danimarka & 98 & 60 & 55 & 20 & 98 & 70 & 0 & 22 & 100 \\
\hline \multicolumn{10}{|l|}{ Yunanistan } \\
\hline İsveç & 20 & 5 & 35 & 0 & 70 & 0 & & 80 & 60 \\
\hline Finlandiya & 80 & 9 & 30 & 10 & 81 & 55 & 0 & 95 & 100 \\
\hline İrlanda & 5 & 0 & 0 & 0 & 0 & 0 & 1 & 50 & 0 \\
\hline Lüksemburg & & & & & & & & & \\
\hline
\end{tabular}

Hafriyat toprağı, inşaat ve yıkıntı atık miktarlarının atık sınıflarına göre (beton, tuğla, kiremit, seramik, ahşap, cam, plastik, metal, yalıtım, karışık, hafriyat ve asfalt) kullanım miktarlarının en detaylı șekilde belirtildiği veriler 1999 yılına ait olup 1990 ile 1998 yılları itibarıyla ülke bazlı olarak Tablo 2 ve Tablo 3'de sunulmuştur [14].

\subsection{Türkiye'de İnşaat ve Yıkıntı Atıklarının Geri Kazanımı}

Türkiye'de atıkların geri kazanım, bertaraf, ön işleme ve ara depolama hizmetleriyle ilgili işletmelerin faaliyetlerini sürdürebilmeleri için geçici faaliyet belgesi veya çevre izin belgesi veya çevre izin ve lisans belgelerine sahip olmaları gerekir. Bu belgeler, çevreye kirletici etkisi yüksek düzeyde olan işletmeler için Çevre ve Şehircilik Bakanlığı; çevreye kirletici etkisi olan ișletmeler için ise Çevre ve Şehircilik İl Müdürlükleri tarafindan verilmektedir. Geçici faaliyet belgesine sahip işletmeler 1 yll içerisinde çevre izin veya çevre izin ve lisans belgesi almaları gerekir [12].

İnşaat ve yıkıntı atıklarının geri kazanımıyla ilgili olarak Türkiye'nin çeşitli illerinde faaliyet gösteren ve çevre izin ve lisans belgesine sahip 1523 işletme ve geçici faaliyet belgesine sahip 410 işletme bulunmaktadır. Bu işletmeler çeşitli inşaat ve yıkıntı atığını geri kazandırarak Türkiye ekonomisine katkıda bulunmaktadır [13]. Tablo 4'de, Türkiye'de çevre izin ve lisans belgesine sahip işletme sayısı ve yaptıkları faaliyetler gösterilmiştir. Buradaki bilgiler, Çevre ve Şehircilik Bakanlığı'nın İzin Lisans ve Geçici Faaliyet
Belgesi Alan İşletmeler sayfasından (https://eizin.cevre.gov.tr/Rapor/BelgeArama.aspx) ilgili atık kodları seçilerek temin edilmiştir. Toplam faaliyet sayısının (1749) işletme sayısından (1523) fazla çıkmasının sebebi, bir işletmenin birden fazla faaliyeti birlikte yürütmesidir. En fazla işletmenin sırasıyla İstanbul, İzmir, Ankara, Bursa, Kocaeli İllerinde olduğu (>100 işletme) ve Adıyaman, Ağrı, Artvin, Bitlis, Erzurum, Giresun, Gümüşhane, Hakkâri, Isparta, Kars, Malatya, Muş, Ordu, Siirt, Tunceli, Bayburt ve Ardahan Illerinde ise işletmenin bulunmadığı görülmüştür.

\subsection{Seçici Yıkım ve Şantiyedeki İşlem Sırası}

Genel olarak bir yıkım işinde yapılması gereken faaliyetler, ana yapının yıkılması, arazinin temizlenmesi ve atık malzemelerin bertaraf edilmesi şeklinde sıralanabilir. Bunların dışında opsiyonel ancak önemi çok büyük olan etken ise hangi malzemelerin tekrar kullanılacağı ve/veya hangilerinin geri dönüşüme gönderileceğinin kararıdır [14].

Yıkıntıdan çıkan malzemelerin sağlıklı bir şekilde geri kazanımını sağlayabilmek için öncelikle malzemelerin niteliklerine göre sökülmesi, yıkımın kontrollü yapılması, atıkların kaynağında ayrılması, tehlikeli atıklardan ayıklanması ve seçerek toplanmasıdır. Bunu, atıkların geçici olarak biriktirilmesi, taşınması, geri kazanılması, değerlendirilmesi ve bertaraf edilmesi izler [8]. 
Tablo 4. Geri kazanım çevre ve lisans belgesine sahip ișletme sayısı ve faaliyet alanları

İnşaat ve Yıkım Atıkları Geri Kazanım Çevre İzin ve Lisans Belgesine Sahip İşletme Sayısı ve Faaliyet Alanları (Mayıs 2020 tarihi itibarıla)

\begin{tabular}{|c|c|c|c|c|c|c|c|c|c|c|c|c|c|c|c|c|c|c|c|c|c|}
\hline Şehir F. Kodu & $\stackrel{\bullet}{\circ}$ & Ð & 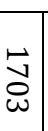 & $\stackrel{Ð}{\triangleright}$ & $\begin{array}{l}\text { Ð } \\
\text { ษ }\end{array}$ & ฑั丶 & $\stackrel{\varpi}{\triangleright}$ & 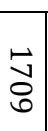 & Top. F. & $\begin{array}{l}\text { Top. } \\
\text { İşl. }\end{array}$ & Şehir F. Kodu & $\stackrel{\bullet}{\circ}$ & $\stackrel{Ð}{O}$ & 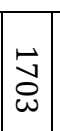 & $\stackrel{Ð}{Ð}$ & 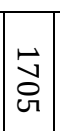 & ฑั丶 & $\stackrel{\bullet}{\circ}$ & $\begin{array}{l}\vdash \\
ઠ \\
\oslash\end{array}$ & Top. F. & Top. İşl. \\
\hline Adana & & 50 & 1 & 12 & 1 & 1 & & 1 & 66 & 56 & Kocaeli & 2 & 63 & 4 & 56 & 5 & 4 & 2 & 5 & 141 & 111 \\
\hline Adıyaman & & & & & & & & & 0 & 0 & Kütahya & 1 & 6 & & 2 & & & & & 9 & 8 \\
\hline Afyon & & 1 & & 1 & & & & & 2 & 2 & Malatya & & & & & & & & & 0 & 0 \\
\hline Ağrl & & & & & & & & & 0 & 0 & Manisa & 1 & 29 & 1 & 15 & 1 & 1 & 1 & 2 & 51 & 41 \\
\hline Amasya & & 2 & & 2 & & & & & 4 & 2 & K.maraş & & 6 & & 15 & & & & & 21 & 21 \\
\hline Ankara & & 55 & 2 & 80 & 1 & 3 & & 4 & 145 & 119 & Mardin & 1 & 5 & 1 & 1 & 1 & 1 & 1 & 1 & 12 & 5 \\
\hline Antalya & & 35 & & 6 & & 1 & & & 42 & 40 & Muğla & & 9 & & 1 & & & & & 10 & 10 \\
\hline Artvin & & & & & & & & & 0 & 0 & Muș & & & & & & & & & 0 & 0 \\
\hline Aydın & & 6 & & & & & & & 6 & 6 & Nevşehir & & 4 & & 4 & & & & 2 & 10 & 7 \\
\hline Balıkesir & & 7 & & 6 & 1 & & & 1 & 15 & 13 & Niğde & & 11 & & 9 & & & & & 20 & 16 \\
\hline Bilecik & & 3 & & 6 & & & & & 9 & 9 & Ordu & & & & & & & & & 0 & 0 \\
\hline Bingöl & & & & 1 & & & & & 1 & 1 & Rize & & 1 & & & & & & & 1 & 1 \\
\hline Bitlis & & & & & & & & & 0 & 0 & Sakarya & & 17 & 1 & 10 & 1 & & & & 29 & 29 \\
\hline Bolu & & 2 & 1 & 2 & 1 & 1 & & & 7 & 3 & Samsun & & 14 & & 8 & & & & & 22 & 21 \\
\hline Burdur & & 1 & & & & & & & 1 & 1 & Siirt & & & & & & & & & 0 & 0 \\
\hline Bursa & 3 & 86 & 2 & 34 & 2 & 2 & 2 & 3 & 134 & 111 & Sinop & & 2 & & & & & & & 2 & 2 \\
\hline Çanakkale & & 1 & & 1 & & & & & 2 & 2 & Sivas & & 1 & & & & & & & 1 & 1 \\
\hline Çankırı & & 2 & & 1 & & & & & 3 & 3 & Tekirdağ & 2 & 36 & 2 & 22 & 2 & 2 & 2 & 2 & 70 & 55 \\
\hline Çorum & & 3 & & 6 & & & & & 9 & 9 & Tokat & & 2 & & & & & & & 2 & 2 \\
\hline Denizli & & 9 & & 16 & & & & & 25 & 20 & Trabzon & & 2 & & 3 & & & & & 5 & 5 \\
\hline Diyarbakır & & 4 & & 1 & & & & & 5 & 6 & Tunceli & & & & & & & & & 0 & 0 \\
\hline Edirne & & 3 & & & & & & & 3 & 3 & Şanlıurfa & & 3 & & & & & & & 3 & 3 \\
\hline Elazı̆̆ & & 1 & & 1 & & & & & 2 & 2 & Uşak & & 9 & & 3 & & & & & 12 & 12 \\
\hline Erzincan & & 1 & & & & & & & 1 & 1 & Van & & 2 & & & & & & & 2 & 2 \\
\hline Erzurum & & & & & & & & & 0 & 0 & Yozgat & & 3 & & & & & & & 3 & 3 \\
\hline Eskișehir & & 11 & & 10 & & & & & 21 & 18 & Zonguldak & & 1 & & 3 & & & & & 4 & 4 \\
\hline Gaziantep & & 81 & & 6 & & & & & 87 & 87 & Aksaray & 1 & 11 & & 4 & & & & & 16 & 15 \\
\hline Giresun & & & & & & & & & 0 & 0 & Bayburt & & & & & & & & & 0 & 0 \\
\hline Gümüșhane & & & & & & & & & 0 & 0 & Karaman & & 2 & & & & & & & 2 & 2 \\
\hline Hakkâri & & & & & & & & & 0 & 0 & Kırıkkale & 2 & 4 & 2 & 8 & 2 & 2 & 2 & 2 & 24 & 10 \\
\hline Hatay & 1 & 6 & 2 & 14 & 2 & 2 & 1 & 2 & 30 & 18 & Batman & & 2 & & 1 & 1 & 1 & & 1 & 6 & 2 \\
\hline Isparta & & & & & & & & & 0 & 0 & Şırnak & & 2 & & & & & & & 2 & 2 \\
\hline Mersin & 1 & 15 & 1 & 5 & 1 & 2 & 1 & 1 & 27 & 18 & Bartın & 1 & & & & & & & & 1 & 1 \\
\hline İstanbul & 2 & 158 & 2 & 131 & 2 & 2 & 2 & 3 & 302 & 287 & Ardahan & & & & & & & & & 0 & 0 \\
\hline İzmir & 1 & 98 & 1 & 50 & 1 & 2 & 1 & 3 & 157 & 143 & Iğdır & & 1 & & & & & & & 1 & 1 \\
\hline Kars & & & & & & & & & 0 & 0 & Yalova & & 5 & & & & & & & 5 & 5 \\
\hline Kastamonu & & 1 & & & & & & & 1 & 1 & Karabük & & 2 & & 4 & & & & & 6 & 6 \\
\hline Kayseri & & 25 & & 10 & & & & & 35 & 35 & Kilis & & 1 & & & & & & & 1 & 1 \\
\hline Kırklareli & & 1 & & 4 & & & & & 5 & 4 & Osmaniye & & 4 & & 9 & & & & & 13 & 12 \\
\hline Kırşehir & & & & 2 & & & & & 2 & 2 & Düzce & 1 & 12 & 1 & 5 & 1 & 1 & 1 & 1 & 23 & 16 \\
\hline Konya & & 32 & & 37 & & 1 & & & 70 & 69 & Genel Toplam & 20 & 972 & 24 & 628 & 26 & 29 & 16 & 34 & 1749 & 1523 \\
\hline
\end{tabular}

1701: Beton. Tuğla, kiremit ve seramik; 1702: Ahşap, cam ve plastik; 1703: Metaller (alaşımları dahil); 1704: Bitümlü karıșımlar, kömür katranı ve katranlı ürünler; 1705:Toprak (kirlenmiş yerlerde yapılan hafriyat dahil), kayalar ve dip tarama çamuru; 1706: Yalıtım malzemeleri ve asbest içeren inşaat malzemeleri; 1708: Alçı bazlı inșaat malzemeleri; 1709: Diğer inșaat ve yıkıntı atıkları 


\subsection{Hurda Karşılığı Yıkım İşlerinde Kamu Mevzuatı}

Yıkım kararı, yapının ekonomik ömrünü tamamlaması ve ihtiyacı karşılayamaması, riskli yapı olması, onarım/güçlendirme maliyetinin yıkıp yeniden yapma maliyetine oranla yüksek çıkması gibi sebeplerle alınabilir [15]. Yıkım kararının, Çevre ve Şehircilik Bakanlığı tarafından riskli yapıların tespiti için yetki verdiği kurum ve kuruluşlar tarafından bina durum raporu ile yapı güvenliğinin belirlenmesine yönelik hazırlanacak rapora istinaden verilmesi uygun olacaktır. Kamu ihalelerinde hurda karşılığı

yıkım işleri kamuya gelir sağlamaya yönelik olduğu için 2886 sayılı Devlet İhale Kanununa göre ihaleye çıkılmaktadır. Bu işler çoğunlukla Kanunun 35 inci maddesinin a bendi (kapalı teklif usulü) ve c bendi (açlk teklif usulü) ile gerçekleştirilir [16].

$\mathrm{Bu}$ çalışmada, kamu binalarının hurda karşılığı yıktırılması süreci incelenerek, elde edilen veriler doğrultusunda kamu gelirlerini artırmaya yönelik çözüm önerilerinin sunulması amaçlanmıştır.

\section{Materyal ve Metot}

Bu çalışmada kamu kurum ve kuruluşlarının 1 Ocak 2016 ile 1 Haziran 2020 yılları arasında yapmış oldukları tüm hurda karşılığı yıkım işleri incelenmiştir. Yıllar itibarıyla ihale sayıları ve muhammen bedeller www.ilan.gov.tr resmi ilan portalı adresinden alınarak tablo halinde sunulmuştur (Tablo 5). İki yüz beş (205) iş için ihaleye çıkan ilgili Kamu kurum ve kuruluşu ile temasa geçilerek yapmış oldukları işler ile ilgili sözleșme bedeli ve muhammen bedel hesaplama yöntemine ilişkin bilgiler talep edilmiştir. Veriye ulaşılan elli dokuz işle ilgili veriler üzerinden çalışma yürütülmüştür.

Tablo 5. 2016-2020 yılları arası hurda karşıllı̆ı yıkım işleri ihale sayısı ve toplam muhammen bedelleri

\begin{tabular}{|r|c|r|}
\hline \multicolumn{1}{|c|}{ İhale Yılı } & İhale Sayısı & $\begin{array}{c}\text { Toplam Muhammen } \\
\text { Bedel (TL) }\end{array}$ \\
\hline $\begin{array}{r}2020 \\
(01.06 .2020 \text { kadar })\end{array}$ & 36 & 0,00 \\
\hline 2019 & 1 & $4.172,00$ \\
\hline 2018 & 3 & $242.000,00$ \\
\hline 2017 & 1 & $103.125,00$ \\
\hline 2016 & 0 & 0,00 \\
\hline TOPLAM & $\mathbf{4 1}$ & $\mathbf{3 4 9 . 2 9 7 , 0 0}$ \\
\hline
\end{tabular}

\section{Bulgular ve Sonuçlar}

Çalışma kapsamına alınan 205 adet hurda karşılığı yıkım işinden elli dokuz adedinin sözleşme bilgilerine ulaşılmıştır. Tablo 6' da işlerin yıllar itibarıyla muhammen bedel ile sözleşme bedeli arasındaki artış katsayısı ve muhammen bedel hesaplama yöntemi yer almaktadır. Tablo 7'de ise elli dokuz adet işin yıllar itibarıla toplam muhammen bedelleri, sözleşme bedelleri ve ortalama artış katsayısı görünmektedir.

Tablo 6'da muhammen bedelin hesaplanmasında dört farklı yöntemin izlendiği görünmektedir: 1) Metraj hesabı yapılmış ve kamu kurumlarının birim fiyatları kullanılmıştır. 2) Metraj hesabı yapılmış ve birim fiyatlar için piyasa araştırması yapılmıştır. 3) Metraj hesabı yapılmamış sadece işin uzmanı firmaların vermiş oldukları tekliflerin ortalaması alınmıştır. 4) Metraj hesabı yapılmamış, ihaleye çlkacak idare kendi tecrübesine dayanarak tahminde bulunmuştur.

Tablo 6, Şekil 3'de grafiksel olarak da gösterilmiştir. Grafikte yıkım işleri sayısı ile sözleşme bedeli/muhammen bedel oranı arasındaki ilişki gösterilmiş ve ciddi dalgalanmalar olduğu görülmüștür (Şekil 3). Muhammen bedel hesaplama yöntemine ile sözleşme bedeli arasında bir ilişki kurulamamıștır. Sözleşme bedeli ile muhammen bedel arasındaki artış oranının düşük olması ya muhammen bedelin değerinde tahmin edildiği ya da ihalede yeterli rekabetin oluşmadığı anlamına gelebilir. Eğer yeterli rekabet oluşmadıysa bu durum ilgili kamu kurumunun gelir kaybına uğramış olabileceğini düșündürmektedir. Muhammen bedel ile sözleşme bedeli arasındaki artış oranının yüksek olması muhammen bedelin değerinde tespit edilemediği ancak ihalede tam rekabetin ya da kısmi rekabetin oluştuğu anlamına gelebilir. Yaptığımız değerlendirmede, muhammen bedelin değerinden az tahmin edilmesi ve ihalede yeterli rekabetin oluşmaması durumunda kamu gelirinde ciddi kayıplar meydana gelebileceği sonucuna ulaşılmıștır. Ülkemizde bu alanda sinırlı sayıda araștırma bulunmaktadır. Çalışmamızın literatürdeki bu eksikliğin giderilmesine ve kamu kaynaklarının daha verimli kullanılmasına katkı sağlayacağı düşünülmektedir.

Çalışmamızdan elde ettiğimiz veriler doğrultusunda önerilerimiz şunlardır:

- Tüm dünyada olduğu gibi ülkemizde de artan nüfus ve şehirleşmeye paralel olarak artış gösteren katı atıkların yönetimi önemli bir konudur. Bu katı atıkların içerisinde yer alan inşaat yıkım atıklarının ekonomik değerinin tespit edilebilmesi, sağlıklı ve yönetilebilir bir geri dönüşüm sistemi kurulabilmesi için tekrar kullanılan, geri dönüștürülen, bertaraf edilen hafriyat toprağı, inşaat ve yıkıntı atıklarının miktarlarının hem merkezi hem de yerel yönetimlerin ortak bir veri tabanı kullanarak yasal bir yönetmelik ile de zorunlu hale getirilerek bir veri tabanında tutulması gerekmektedir.

- 4734 sayll Kamu İhale Kanunu ile ihale edilen işlerde bulunan tebliğ ve yönetmeliklerde olduğu gibi 2886 saylı Devlet İhale Kanunu için de tebliğ ve 
yönetmelikler düzenlenerek bu kanun esaslarına göre ihale edilen hurda karşılığ yıkım işlerinde de saydamlığın ve kamuoyu denetiminin sağlanabilmesi için ihale tarihlerinin ilan edilmesi, şartnamelerin yayınlanması ve ihale sonuçları ile sözleşme bilgilerinin tıpkı 4734 Sayılı Kamu İhale Kanunu'nun kullanıldığı Elektronik Kamu Alımları Platformu (EKAP) benzeri bir veri tabanına kaydedilmesi faydalı olacaktır.
2886 sayılı Devlet İhale Kanunu kapsamında İhaleye çıkılacak hurda karşılığı yıkım işlerinin muhammen bedellerinin daha gerçekçi hesaplanabilmesi için ilave tebliğ ve yönetmelikler ile bir sınır çizilmesi önem arz edecektir.

Tablo 6. Muhammen bedel ile sözleşme bedeli arasındaki ilişki

\begin{tabular}{|c|c|c|c|c|c|}
\hline İlan Tarihi & $\begin{array}{c}* \text { *Sb/Mb } \\
\text { (Artış } \\
\text { Katsayısı) }\end{array}$ & $\begin{array}{c}\text { Muhammen Bedel Hesaplama } \\
\text { Yöntemi }\end{array}$ & $\begin{array}{l}\text { İlan } \\
\text { Tarihi }\end{array}$ & $\begin{array}{c}\text { *Sb/Mb } \\
\text { (Artıs } \\
\text { Katsayısı) }\end{array}$ & $\begin{array}{l}\text { Muhammen Bedel } \\
\text { Hesaplama Yöntemi }\end{array}$ \\
\hline 2020 & 1,69 & Bilinmiyor & 2018 & 1,23 & Metraj hesabı + birim fiyat \\
\hline 2020 & 1,01 & Metraj hesabı + birim fiyat & 2018 & 4,86 & Bilinmiyor. \\
\hline 2020 & 101,70 & Metraj hesabı + piyasa araștırması & 2018 & 1,52 & Bilinmiyor. \\
\hline 2020 & 4,57 & Piyasa araștırması & 2018 & 104,17 & Metraj hesabı + birim fiyat \\
\hline 2020 & 1,56 & Piyasa araștırması & 2018 & 1,13 & Bilinmiyor. \\
\hline 2020 & 9,63 & Metraj hesabl + birim fiyat & 2018 & 1,51 & Metraj hesabı + birim fiyat \\
\hline 2020 & 1,75 & Metraj hesabl + birim fiyat & 2018 & 1,63 & Piyasa araştırması \\
\hline 2020 & 1,05 & Bilinmiyor. & 2018 & 14,81 & Bilinmiyor. \\
\hline 2020 & 2,10 & Bilinmiyor. & 2018 & 10,88 & Metraj hesabı + birim fiyat \\
\hline 2019 & 1,16 & Metraj hesabı + birim fiyat & 2018 & 1,85 & Metraj hesabı + birim fiyat \\
\hline 2019 & 2,47 & Bilinmiyor. & 2018 & 2,17 & Bilinmiyor. \\
\hline 2019 & 2,41 & Metraj hesabı + birim fiyat & 2018 & 1,32 & Bilinmiyor. \\
\hline 2019 & 1,18 & Bilinmiyor. & 2018 & 1,44 & Metraj hesabı + birim fiyat \\
\hline 2019 & 2,58 & Metraj hesabı + birim fiyat & 2018 & 3,86 & Bilinmiyor. \\
\hline 2019 & 1,33 & İdarenin tahmini & 2018 & 1,15 & Piyasa araștırması \\
\hline 2019 & 6,94 & Bilinmiyor. & 2018 & 2,29 & Bilinmiyor. \\
\hline 2019 & 1,07 & Bilinmiyor. & 2018 & 1,84 & Bilinmiyor. \\
\hline 2019 & 1,13 & Bilinmiyor. & 2017 & 1,93 & Metraj hesabı + birim fiyat \\
\hline 2019 & 1,22 & Bilinmiyor. & 2017 & 1,15 & Metraj hesabı + birim fiyat \\
\hline 2019 & 3,68 & Metraj hesabı + birim fiyat & 2017 & 1,72 & Metraj hesabı + birim fiyat \\
\hline 2019 & 2,50 & Piyasa araștırması & 2017 & 1,47 & Piyasa araștırması \\
\hline 2019 & $285.000,00$ & Piyasa araștırması & 2017 & 3,97 & Bilinmiyor. \\
\hline 2019 & 1,28 & Metraj hesabl + birim fiyat & 2017 & 1,11 & Bilinmiyor. \\
\hline 2019 & 1,79 & Metraj hesabı + birim fiyat & 2017 & 5,22 & Bilinmiyor. \\
\hline 2019 & 7,76 & Piyasa araștırması & 2017 & 2,60 & Bilinmiyor. \\
\hline 2019 & 61,71 & Metraj hesabı + birim fiyat & 2017 & 8,49 & Bilinmiyor. \\
\hline 2019 & 1,23 & Bilinmiyor. & 2016 & 26,58 & Piyasa araştırması \\
\hline 2019 & 3,22 & Bilinmiyor. & 2016 & 1,50 & Metraj hesabı + birim fiyat \\
\hline 2019 & 2,36 & Bilinmiyor. & 2016 & 1,01 & Piyasa araştırması \\
\hline 2019 & 15,73 & Piyasa araștırması & & & \\
\hline
\end{tabular}

*Sb: Sözleșme bedeli; Mb: Muhammen bedel

Tablo 7. İhale yılı itibarıyla toplam muhammen bedel ile toplam sözleșme bedelleri

\begin{tabular}{|c|c|c|c|c|}
\hline İhale Yılı & İhale Sayısı & Toplam Muhammen Bedel (TL) & Toplam Sözleşme Bedeli (TL) & $\begin{array}{c}\text { Artıs } \\
\text { Katsayısı }\end{array}$ \\
\hline $\begin{array}{r}2020 \\
(01.06 .2020 \text { kadar })\end{array}$ & 9 & $2.820 .191,69$ & $4.155 .066,00$ & 1,47 \\
\hline 2019 & 21 & $3.345 .779,51$ & $7.729 .207,00$ & 2,31 \\
\hline 2018 & 17 & $9.333 .515,35$ & $15.266 .967,18$ & 1,64 \\
\hline 2017 & 9 & $1.534 .695,52$ & $3.796 .553,00$ & 2,47 \\
\hline 2016 & 3 & $807.848,13$ & $1.516 .300,00$ & 1,88 \\
\hline TOPLAM & 59 & & ORTALAMA ARTIŞ KATSAYISI & 1,95 \\
\hline
\end{tabular}


Şekil 3. Muhammen bedel ile sözleşme bedeli arasındaki artış katsayısı

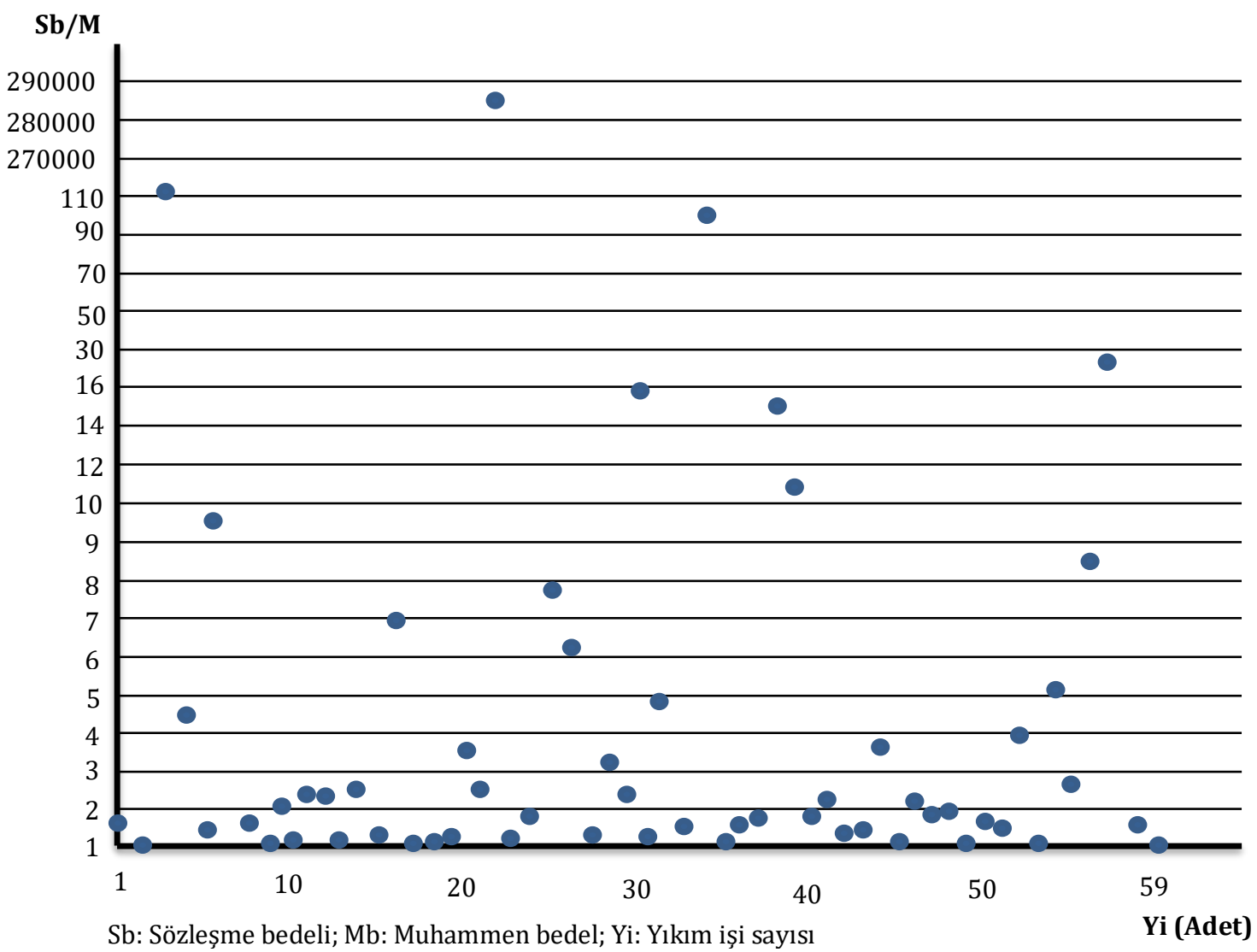

\section{Etik Beyanı/Declaration of Ethical Code}

$\mathrm{Bu}$ çalışmada, "Yükseköğretim Kurumları Bilimsel Araştırma ve Yayın Etiği Yönergesi" kapsamında uyulması gerekli tüm kurallara uyulduğunu, bahsi geçen yönergenin "Bilimsel Araștırma ve Yayın Etiğine Aykırı Eylemler" başlığı altında belirtilen eylemlerden hiçbirinin gerçekleştirilmediğini taahhüt ederiz.

\section{Kaynakça}

[1] Silva R.V., Brito J. de ve Dhir R. K. 2014. Properties and Composition of Recycled Aggregates from Construction and Demolition Waste Suitable for Concrete Production. Construction and Building Materials, 201-217.

[2] Eurostat, 2020. Waste Statistics, https://ec.europa.eu/eurostat/statisticsexplained/index.php/Waste_statistics\#Total_wa ste_generation, ISSN 2443-8219 (Erişim Tarihi: 04.06.2020).

[3] Eurastat, 2019.Record Recycling Rates and Use of Recycled Materials in the EU, Eurostat Your key to European statistics, https://ec.europa.eu/eurostat/documents/299 5521/9629294/8-04032019-BP-EN.pdf/295c23 02-4ed1-45b9-af86-96d1bbb7acb1

(Erişim Tarihi:04.06.2020).
[4] Eurastat, 2018. Recovery Rate of Construction and Demolition Waste, https://ec.europa.eu/ eurostat/tgm/refreshTableAction.do?tab=table \&plugin $=1 \&$ pcode $=$ cei_wm $040 \&$ language $=$ en (Erişim Tarihi:04.06.2020).

[5] T.C. Bilim, Sanayi ve Teknoloji Bakanlığı, Sanayi Genel Müdürlüğü, 2014. Ulusal Geri Dönüşüm Strateji Belgesi ve Eylem Belgesi (2014-2017), 113s, Ankara.

[6] T.C. Çevre ve Şehircilik Bakanlığı Çevre Yönetimi Genel Müdürlüğü, 2017. Ulusal Atık Yönetimi ve Eylem Planı (2016-2023), 140s, Ankara.

[7] T.C. Çevre ve Şehircilik Bakanlı̆̆l, 2019. Evsel Atıklar Proje Şube Müdürlüğü. İnşaat ve Yıkıntı Atıklarının Geri Kazanımı. Marmara Belediyeler Birliği. http://marmara.gov.tr/UserFiles/ Attachments/2019/12/20/5dd64249-8e854a09-89e4-c9ad866b3794.pdf. Tarihi:03.06.2020).

[8] Resmi Gazete. Hafriyat Toprağı, 2004. İnşaat Ve Yıkıntı Atıklarının Kontrol Yönetmeliği 25406, 11s, Ankara.

[9] Environmental Protection Agency, 2002. European Waste Catalogue and Hazardous Waste List. s.l., Ireland: Environmental Protection Agency, ISBN: 1-84095-083-8. 
[10] Commission of The European Communities, 2010. EUROSTAT Guidance on EWC-Stat Waste Categories.

[11] Resmi Gazete. Atık Yönetimi Yönetmeliği, 2015. 29314, 208s, Ankara.

[12] T.C. Çevre ve Şehircilik Bakanlı̆̆ı. Çevresel İzin ve Lisans İstatistikleri Bülteni, 2019. Çevresel İzin ve Lisans İstatistikleri Haber Bülteni. https://webdosya.csb.gov.tr/db/ced/menu/izin -ve-lisans-haber-bulteni_2019_2020033101500 3.pdf. (Erişim Tarihi:19.06.2020).

[13] Çevresel Etki Değerlendirmesi, İzin ve Denetim Genel Müdürlüğü, 2020. İzin ve Lisans İşlemleri,
Çevresel İzin ve Lisans İstatistikleri, https://ced.csb.gov.tr/izin-ve-lisans-islemleri-i82206. (Erişim Tarihi:19.06.2020).

[14] Symonds Group Ltd. European Commission, 1999, Construction and Demolition Waste Management Practices, and Their Economic Impacts.

[15] Aktaş Z.2015. Bina Yıkım Atıklarının Altyapı Projelerinde Değerlendirilmesi, Uzmanlık Tezi, İller Bankası Anonim Şirketi, Ankara.

[16] Resmi Gazete, 1983. 2886 sayıl Devlet İhale Kanunu. 22 (18161), 573s, Ankara. 